\title{
Big data analysis of loT-based supply chain management considering FMCG industries
}

\author{
Hamed Nozari ${ }^{a}$ \\ E-mail: Ham.nozari.eng@iauctb.ac.ir

\section{Mohammad Fallah} \\ E-mail: Mohammad.fallah43@yahoo.com
}

\author{
Hamed Kazemipoor ${ }^{\mathrm{a}}$ \\ E-mail: Hkazemipoor@yahoo.com
}

\section{Seyed Esmaeil Najafi ${ }^{\mathrm{b}}$}

E-mail: E.najafi@srbiau.ac.ir

\author{
a Islamic Azad University, Central Tehran Branch \\ Address: Hamila Blvd., Poonak Sqr., Tehran 1469669191, Iran \\ b Islamic Azad University, Tehran Branch, Science and Research \\ Address: Daneshgah Blvd., Simon Bulivar Blvd., Tehran 1477893855, Iran
}

\begin{abstract}
Supply chain is one of the main pillars of manufacturing and industrial companies whose smartness can help business to be intelligent. To this end, the use of innovative technologies to make it smart is always a concern. The smart supply chain utilizes innovative tools to enhance quality, improve performance and facilitate the decision-making process. Internet of things (IoT) is one of the key components of the IT infrastructure for the development of smart supply chains that have high potential for creating sustainability in systems. Furthermore, IoT is one of the most important sources of big data generation. Big data and strategies for data analysis as a deep and powerful solution for optimizing decisions and increasing productivity are growing rapidly. For this reason, this paper attempts to examine informative supply chain development strategies by investigating the supply chain in FMCG industries as a special case and to provide a complete analytical framework for building a sustainable smart supply chain using IoT-based big data analytics. The proposed framework is based on the IoT implementation methodology, with emphasis on the use of input big data and expert reviews. Given the nature of the FMCG industry, this can lead to better production decisions.
\end{abstract}

Key words: big data; internet of things (IoT); IoT-based supply chain management; FMCG supply chain.

Citation: Nozari H., Fallah M., Kazemipoor H., Najafi S.E. (2021) Big data analysis of IoT-based supply chain management considering FMCG industries. Business Informatics, vol. 15, no 1, pp. 78-96. DOI: 10.17323/2587-814X.2021.1.78.96 


\section{Introduction}

An intelligent supply chain is an innovative supply chain that utilizes information technology and other technology tools to improve efficiency, improve processes and increase service levels. In today's world, the modern business environment is dealing with data and this has created many challenges and opportunities. The volume of date produced in various sectors is enormous, and their analysis requires specific capabilities and technologies. These technologies include information technology, robotics, internet technologies, commercial automation, Augmented reality (AR) and Virtual Reality (VR) technologies among others. These developments are known as the digital economy or industry 4.0. This provides a great deal of demand for supply chain management by increasing consumers' expectation of service level and delivery time [1]. The advent of IoT and ICT has changed many of the concepts so that the "smart supply chain" can be one of them [2]. Therefore, these supply chains (which actually make business smarter) use information technology to be intelligent and efficient in using resources to maximize the quality of businesses. IoT is one of the key components of the information technology infrastructure in smart supply chain management due to its high potential for increasing the sustainability of the business environment [3]. IoT is associated with big data analytics, which is clearly leveraging many areas of the business to optimize energy efficiency and reduce effects damaging to the environment [4]. Datadriven applications and IoT have a huge impact on facilitating and improving the sustainable development process of the environment [5]. In general, the development of IoT, as a computational paradigm and analytical process of big data, promotes sustainable smart city initiatives and programs in the environmental and technological fields of developed countries [6]. In the context of a sustainable smart supply chain, the volume of data produced is beyond the imagination that is produced using different technologies. IoT technologies include a variety of sensors, data processing systems, wireless communication networks, and system activators in the physical environment [5]. Despite increasing research on IoT and big data related applications, most research on IoT has focused more on urban development, and the applications of these technologies in businesses are often less considered. Therefore, the main question of the present study is how and to what extent can the information perspective of a sustainable smart supply chain be enhanced by the use of IoT and big data processing?
Of course, in recent years, with the development of the concept of IoT and its close relationship with data analytics, there has been a great deal of research in this field and this research is growing. To this end, some researchers have tried to show that using IoT data can improve port-based intermodal supply chain performance [7]. Other research also addressed the role and impact of using IoT and blockchain in supply chain management in industries such as agriculture. Research has shown that the use of these technologies can fundamentally change the economics of these industries [8]. Although the challenges and opportunities for using IoT-derived big data in the manufacturing industry have also been addressed in research [9], but so far, there has been no framework for using the big data coming from connected devices. At the moment, there is a lack of innovative solutions based on big data and IoT. Therefore, in this study, we try to explore supply chain informative improvement solutions using IoT. The supply chain of the FMCG (fastmoving consumer goods) industry was considered as a special case in this research. These industries are of great importance due to the nature of production as well as the distribution of products. So, in addition to reviewing the literature and previous research, the opinions of experts active in FMCG industries were also used for this research. In this regard, this paper presents an analytical framework and describes the ways of generating big data in the field of sustainable intelligent supply chain (in the FMCG supply chain). This framework is based on the 4-step process of IoT implementation in intelligent business. This framework illustrates how the use of Big Data Input based on IoT devices can be used to make decisions in the supply chain in the FMCG industries. This framework illustrates the direct relationship between data entry (derived from IoT) and final decision-making in the FMCG supply chain network. This work provides a basis for supply chain researchers to develop analytical frameworks for future research. The framework introduced here can be developed, tested and evaluated in empirical research and will lead to deeper studies of the smart supply chain.

The rest of the paper is organized as follows. Section 1 presents a review of the literature in terms of big data and the internet of things. Section 2 presents smart businesses. The smart supply chain is illustrated in Section 3 considering supply chain and IoT and big data in the FMCG supply chain. In Section 5 a sustainable smart supply chain framework is provided, and lastly, the conclusions are presented. 


\section{Literature review}

In order to illustrate the effects of big data and IoT concepts on supply chain management, a literature review of big data and IoT technologies is provided in this section.

\subsection{Big data}

The term 'big data' was first proposed by Cox and Ellsworth in 1997 as an interesting challenge for computer systems, when data sets do not fit in main memory or when they do not fit even on local disk or remote disk [10]. In recent decades, 'big data' concept refers to greatly increased amounts of data that are constantly generated in various fields. Generally, big data could be defined as the datasets that could not be captured, stored, managed and analyzed by IT systems of an organization within a particular time frame [11]. It is assumed that as technology advances over time, the size of datasets that qualify as big data will also increase and it will vary by sectors, in many of which big data can range from a few dozen terabytes to multiple petabytes [12]. Some scholars use the notation of ' $\mathrm{V}$ ' for some characteristics to describe 'big data'. Some of them [13-16] defined big data in terms of 3 Vs, Velocity, Variety and Volume, in which 'velocity' refers to the speed of data generation and/or frequency of data delivery, 'variety' represents a large variety of sources and formats from which data are generated, and 'volume' denotes the large amount of data [14]. In some definitions of big data, another $V$ has been added (known by $4 \mathrm{Vs}$ ) as Value referring to the significance of extracting economic benefits from the big data [17, 18]. Furthermore, White [19] proposed an additional characteristic as Veracity, in order to stress the importance of sufficient quality of the data and the level of trust in different data sources. In addition, three main characteristics of 'big data' were identified by IDC [20] as the data itself, its analytics and the presentation of the results obtained by analytics. Boyd and Crawford [21] suggested a more holistic description of 'big data' that includes a cultural, technological, and scholarly phenomenon that rests on the interplay of technology, analysis, and mythology. In this definition, the technology aspect refers to storage and computation power to process and analyze datasets, the analysis aspect is related to patterns identification for economic, social, technical, and legal claims or the type of analysis implemented on datasets, and the mythology aspect includes the widespread belief that the big data offers a higher form of intelligence. Therefore, 'big data' can be defined as an approach to manage and analyze the V's characteristics to establish competitive advantages as well as creating sustained value delivery and measuring performance [18]. Typically, the 5 Vs model or its derivations is known as one of the most common definitions of the 'big data' [9].

Big data analytic (BDA) is defined as one of the key foundation technologies including analytics research, alongside Text Analytics, Web Analytics, Network Analytics and Mobile Analytics, and is applied to describe data mining and statistical analysis using business intelligence and analytics technologies [22]. Beyond data analytics decisions in customer marketing and customer research, Big Data Analytics (BDA) has increasingly changed the business value propositions of product businesses and services by increasing the efficiency of physical products and providing personalized services [23]. In this case, security is certainly one of the most important issues in the production and use of critical big data. But research shows that data security concerns are not key factors in the use of big data analytics [24]. For this reason, a growing number of firms are accelerating the deployment of big data analytics plans aimed at developing critical insights that can ultimately provide them with competitive advantage [25].

Some scholars described BDA as the "fourth paradigm of science" [26] or even "the next frontier for innovation, competition, and productivity" [12]. In fact, BDA can enable data miners and researchers to analyze a large volume of data that may not be tackled by applying traditional tools [27]. BDA can be employed in various tools such as social media, portable devices like laptops and smartphones, automatic identification systems enabling the IoT and cloud-enabled platforms in order to support all organizational business processes [28].

The extensive applications of IoT have made BDA challenging due to the processing and collecting of data from different sensors in the IoT environment. So, in the IoT big data analytics perspective, a variety of IoT data are examined to reveal trends, unseen patterns, hidden correlations, and new information [27, 29]. As recognized by statistics, the number of sensors will be increased by 1 trillion in 2030 [30] that can be led to the growth of big data and subsequently huge resources will be required. To effectively communicate among various deployed applications, IoT services can provide appropriate resources and intensive applications of the platforms. It is found that the integration of IoT and big data can help address issues on storage, processing, data analytics, and visualization tools [31]. In accordance with the requirements of IoT applications, different analytic types are used including real-time, off-line, memory-level, business intelligence, and massive level 
analytics categories [32]. Real-time analytics is usually implemented on data collected from sensors, according to parallel processing clusters using traditional relational databases and memory-based computing [31, 33]. If there is no need for a quick response, off-line analytics can be applied and when the size of data is smaller than the cluster's memory, memory-level analytics is employed [32]. Business intelligence (BI) analytics is utilized when the size of data is larger than the memory, so data can be imported to the BI analysis environment [34]. Additionally, if the size of data is much greater than the whole capacity of the BI analysis product in addition to the traditional databases, massive analytics is used [35]. Big data analytics together with the IoT concept are usually employed to improve decision making. So, increasing the amount of data in IoT applications can lead to development of big data analytics. Moreover, employing big data technologies in IoT can facilitate future research advances and business models of IoT [31].

The IoT-based data in a supply chain are definitely considered as big data, satisfying the sufficient conditions in terms of the V's characteristics. In general, IoT data is constantly generated in real time within the supply chain processes in addition to providing a variety of data formats [36]. Moreover, when a large number of tags and sensors are connecting through the internet, an unprecedented number of transactions and amounts of data are generated $[37,38]$. In this regard, BDA by representing a critical source of meaningful information can help supply chain stockholders to improve their insights for competitive advantage [39] in addition to reducing their exposure to various risks [40]. Furthermore, it was reported that BDA can lead to increasing the efficiency and profitability of supply chains by maximizing speed and visibility, improving supply chain stakeholders' relationships, and enhancing supply chain agility [41]. In addition, BDA results in faster time to market and the potential for superior revenue recognition [28]. It is found from a survey within 720 firms that, although $64 \%$ of respondents were planning to invest in BDA projects, less than $8 \%$ of them had actually deployed a solution [42].

Recent research in recent years has addressed the issue of big data and its impact on the supply chain from multiple angles. Some research has specifically provided frameworks for evaluating supply chain performance using big data [43] and some research has addressed the effects of agility using big data [44]. But in operational terms, most academic papers in this field focus on describing the term and its key factors as well as making predictions about the level of impact it will have in cer- tain sectors in the future [45-47]. There are a limited but growing number of publications concentrated on industrial cases, education, sports, public sector, mining and logistic [48-52]. However, there is still a lack of case studies of big data analysis in IoT supply chain management especially in FMCG industries.

\subsection{Internet of things}

The term 'internet of things' (IoT) was coined by Kevin Ashton in the late 1990s in order to examine work concerning Radio-Frequency Identification (RFID) infrastructure [53, 54]. Subsequently, the new concept of sensors and actuators through a wireless sensor network came to sense and monitor objects [55] In recent decades, the modern concept of IoT includes GPS devices, smartphones, social networks, cloud computing and data analytics [56]. In general, not only IoT tracks the objects and collects the new data but also combine them to generate a greater level of information [54]. The IoT concept has developed to describe a global network of infrastructure where things, wireless networks, and computing abilities combine to form a network of information [57]. So that, the recent adoption of IoT has witnessed smart cities with regard to developing intelligent systems, such as smart energy, smart office, smart agriculture, smart water, smart retail, smart transportation, smart healthcare, etc. [58] The rapidly growing number of interlinked "things" in the so called industrial internet of things (IIoT) offers various options for connecting the physical and digital spheres together [59]. In Europe, IoT is one of the founding technologies of Industry 4.0 as the integration of information and communications technologies with industrial technology [60]. The 'things' in IIoT can include smart machines, smart products, and smart services. IoT can be applied in an incredibly wide range of application scenarios [61]. Some instances of physical items that IoT connects to the digital worlds include actuators, sensors, electronic toll devices in vehicles, washing machines, lighting systems, front door locks, thermometers, air conditioning units and much more [54, 57, 62-64].

Recent data IoT protocols are specifically designed for IoT devices that use low-power wide-area networks to connect at a low bit rate a wide variety of devices with low cost and minimum energy consumption [65]. Lee and Lee [66] presented that IoT technologies, as essential parts in the deployment of successful IoT-based products and services, are classified into five categories as radio-frequency identification, wireless sensor net- 
works, middleware, cloud computing, IoT applications. On the other hand, it is recognized that IoT are faced with several challenges such as scalability, self-Organizing, data volumes, data interpretation, interoperability, automatic discovery, software complexity, security and privacy, fault tolerance, power supply, and wireless communications $[67,68]$. However, it is important for new designs to support the development of smart and connected products in order to expand opportunities for new functionalities and increase capabilities that cut across and transcend traditional product boundaries [69]. In Figure 1, the architecture of the internet of things is shown. As can be seen in the figure, this architecture has four stages. In summary, these four steps include data acquisition, data analysis, data processing and computation, and ultimately the use of data to improve performance. This model can be the basis for presenting industrial frameworks in different industries or different organizational units.

In light of the future of IoT that can enable everyone to access and contribute rich information about things and locations, several developments towards the IoT have concentrated on the combination of Auto-ID and networked infrastructures in logistics and product life cycle applications [70]. Sun [71] claimed that enterprises with IoT can monitor their every product in real time. Therefore, due to analyzing the information generated from every procedure as well as more accurate forecasting, the abilities of enterprises for responding to the market can be improved [71]. Wortmann and Fluchter [64] discussed that existing business models may have to be adapted or re-defined based on a new positioning of products in the IoT and even entire industry boundaries may need to be re-assessed in today's competitive marketplace. Moreover, it was argued that the IoT promises future new technologies when related to big data, cloud and distributed computing in order to develop smarter applications as soon [72]. It can be seen that this concept is expanding day by day and provides high value for all activities in life and business In recent years this concept has been more broadly referred to as the internet of everything (IoE). The IoE connects people, organizations, and smart things, and also promises to fundamentally change the way we live, work and interact, and may redefine a wide range of industry segments [73].

The application of IoT in supply chain management consists of several areas such as cost-saving, inventory accuracy and product tracking [56]. In order to monitor the good, it should be tracked in both indoors by developing RFID system, and outdoors by mainly using GPS [74]. Tao et al. [75] designed an IoT-based framework to achieve intelligent perception and access of various manufacturing resources. Gnimpieba et al. [76] proposed the architecture of a platform based on advanced technologies related to IoT for a better collaboration and interoperability enhancement in supply chain. Verdouw et al. [77] provided a reference architecture for IoT-based supply chain information systems in the agricultural industry. Decker et al. [78] described several benefits of IoT connected to sourcing and examined the impact of the cost of sensors and alerts on the unit purchase cost. It was found that smart manufacturing can lead to smarter decisions and more efficient operations in the factory and supply chain visibility based on real-time information [56] $\mathrm{Xu}$ [79] believed that successful supply chain quality management depends on more sophisticated systems.
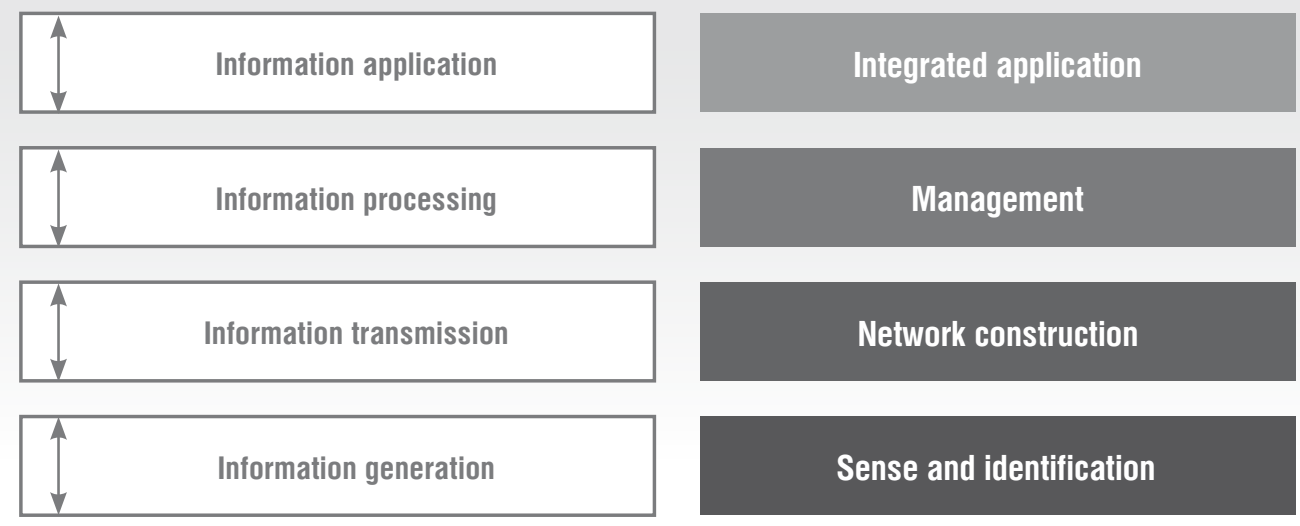

Fig. 1. Four-layer architecture of internet of things 
Chen [80] proposed the intelligent IoT-enabled system in green supply chain to simulate complex system by linked physical and digital objects with relationships. Yan et al. [81] illustrated an intelligent supply chain integration and management system to provide flexible and agile approaches to facilitate the resource sharing and participant collaboration in the whole life cycle of supply chain. Parry et al. [82] demonstrated how the IoT may be operationalized in the domestic setting to capture data on a consumer's use of products and the implications for reverse supply chains. Kang et al. [36] proposed a sensor-integrated RFID data repositoryimplementation model that can integrate and store a large amount of IoT-generated data collected from supply chain processes. Thoben et al. [83] indicated that smart manufacturing can include different technologies such as IoT, robotics/automation, big data analytics and Cloud computing.

Therefore, due to lack of academic publications that address big data analysis of a smart supply chain in an IoT environment, it is important to investigate the applications and interactions of the concepts of BDA and IoT in supply chain management.

\section{Smart businesses}

Organizations are pursuing new technologies in their business for a variety of reasons, including facilitating activities, reducing human errors, decreasing costs and speeding up services and product deliveries [2]. One of the latest computer-related technologies, also referred to as information technology developments, is IoT, which creates value for both businesses and customers [84]. IoT enables the fabrication of digital and physical structures and provides a whole new level of complete applications and services that must be used with regard to environmental sustainability. In the context of sustainable smart businesses, increasing the volume of data production is beyond imagination and the sheer volume of current available information from various business areas are so valuable to be used by IT planners and IT professionals in order to promote environmental sustainability. This phenomenon has created a huge revolution in industry [85]. IoT is one of the major sources of big data generation. As mentioned in the previous section, IoT technologies include a variety of sensors, data processing systems, wireless communication networks, and system activators in the physical environment [5]. Moreover, IoT can improve the performance of value chain management and smart commerce by implementing functional technologies and transform- ing product and other artifacts into smart items in all parts of the value chain (suppliers, manufacturers and retailers), which in turn leads to flexibility, high reliability, and proper information monitoring throughout the supply chain [86]. So a smart business can be introduced as a large, organic system that integrates many subsystems and components. In other words, business intelligence combines the enhancing and effective digital telecommunications networks (nerve), embedded information (brain), sensors and labels (sensory organs) and software (knowledge and cognitive competence). Figure 2 shows an example of an IoTbased smart business [2]. As can be seen in Figure 2, the relationship between the market, suppliers as well as manufacturers is based on local as well as wireless communication in smart business. In this case, the integration and refinement and optimization of data from these sources ensure system intelligence. A smart business can have many benefits, some of which are [87-90]:

$\checkmark$ decreasing the use of vital resources and water;

$\downarrow$ reduction of the air pollution;

$\downarrow$ proper use of the existing fundamental constraints and then increasing personal satisfaction and reducing the need for conventional venture capitalists;

$\checkmark$ how to deal with many abuses;

$\downarrow$ increasing business investment by disseminating continuous information about activity in different geographic areas.

The IoT-based supply chain is then discussed as one of the most important pillars of smart businesses.

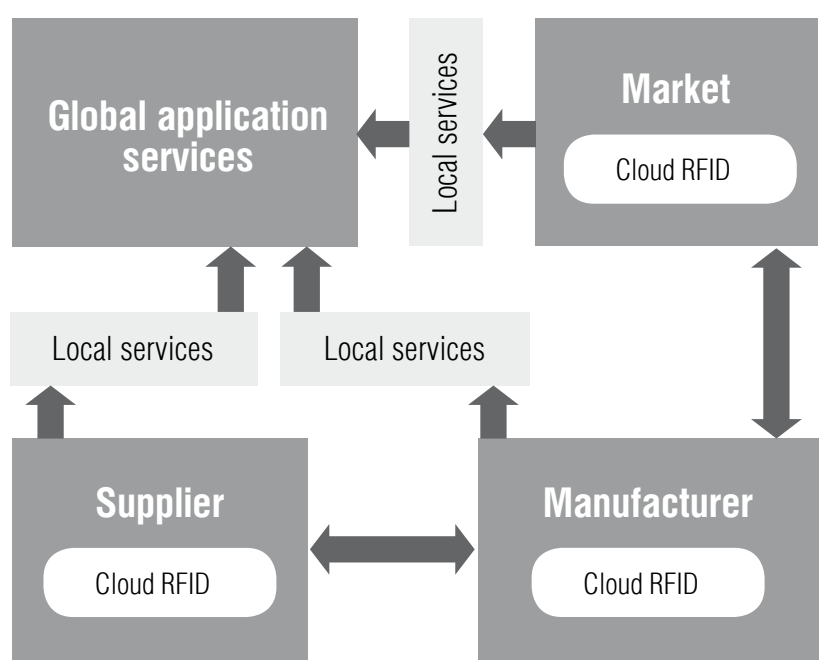

Fig. 2. Smart business based on I0T 


\section{Smart supply chain 3.1. Supply chain and IoT}

Supply chain management integrates supply and demand processes throughout the organization. Supply chain management claims to offer solutions to help industry professionals better manage the entire supply chain from suppliers to end customers. Supply chain systems have been empowered using the internet and this has led to increased efficiency and productivity in the supply chain. In traditional supply chain management systems, there exist several problems such as overstocking, delivery delays and stock out. These problems return to several factors such as complexity and uncertainty as exist in real supply chains [91]. IoT technology can help the industrial system to manage these uncertainties and improve supply chain efficiency [92]. The benefits of managing an electronic supply chain can include operational and strategic improvement in communications, collaboration and coordination to meet organizational barriers [93]. Thus, IoT smart devices enable supply chain companies to reduce the costs of the knowledge acquisition process. Using IoT in supply chain management makes it smarter and has the following features [91]:

$\downarrow$ the entire system must connect through the use of intelligent objects and IT systems;

$\downarrow$ their performance is optimized by large-scale decision making;

$\downarrow$ all processes must be automated and therefore less efficient resources will be lost;

$\downarrow$ all stages of the supply chain are integrated;

$\downarrow$ new values evolve through solutions to meet new needs.

Firms will put resources into the IoT to build deceivability of materials stream as well as decreasing the loss of materials, and lower circulation costs. This is delineated in Figure 3.

In the current paper, we selected the FMCG (fastmoving consumer goods) supply chain as a special case. So in the following, the term 'supply chain' refers to the supply chain of FMCG industries.

Due to the nature of products in the FMCG industry, supply chain management has a special place in this industry. Usually the products in these industries can be perishable and therefore the distribution and delivery system in a given time is of great importance. Freight tracking links and interconnections with suppliers and end users are other features of the supply chain in these industries. As the FMCG products meet many people's

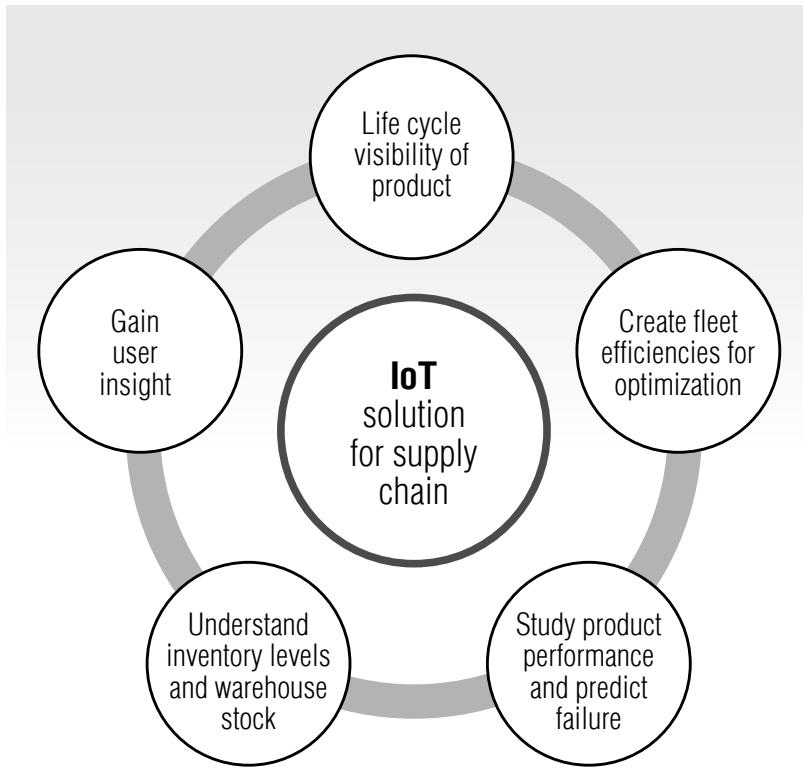

Fig. 3. The applications of IoT in the supply chain [94]

daily needs, so their demands are high, and meeting the demands at the right time is another important component of the supply chain in these industries. Therefore, IoT, as one of the most important solutions for the production, maintenance and tracking of data, can have a huge impact on the supply chain of these companies and can have many effects. A simple diagram of FMCG supply chain management is presented in Figure 4. Supply chain improvement is essential for FMCG companies. Supply chain innovation is defined as the change in a supply chain network, supply chain technology or supply chain process or a combination of these that can be incorporated into the functions of a company, an entire company, industry or supply chain to enhance new value for stakeholders [95]. Network information of warehouse, production, distribution and other communications are gradually generated by the system of sensors, RFID tags, meters, actuators, GPS and various frameworks. Companies will put resources into the IoT to build deceivability of materials stream in addition to decreasing the loss of materials, and lower circulation costs. As IoT comes to the core business forms, a large number of corporate resources are converted into green store networks, and the use of IoT will become a matter of great excitement for bosses [96]. But security risks analysis on the IoT should always be considered.

One of the most important things about the IoT is that it is one of the largest data producers for an intelligent system created from internet-related tools. So gadgets are 


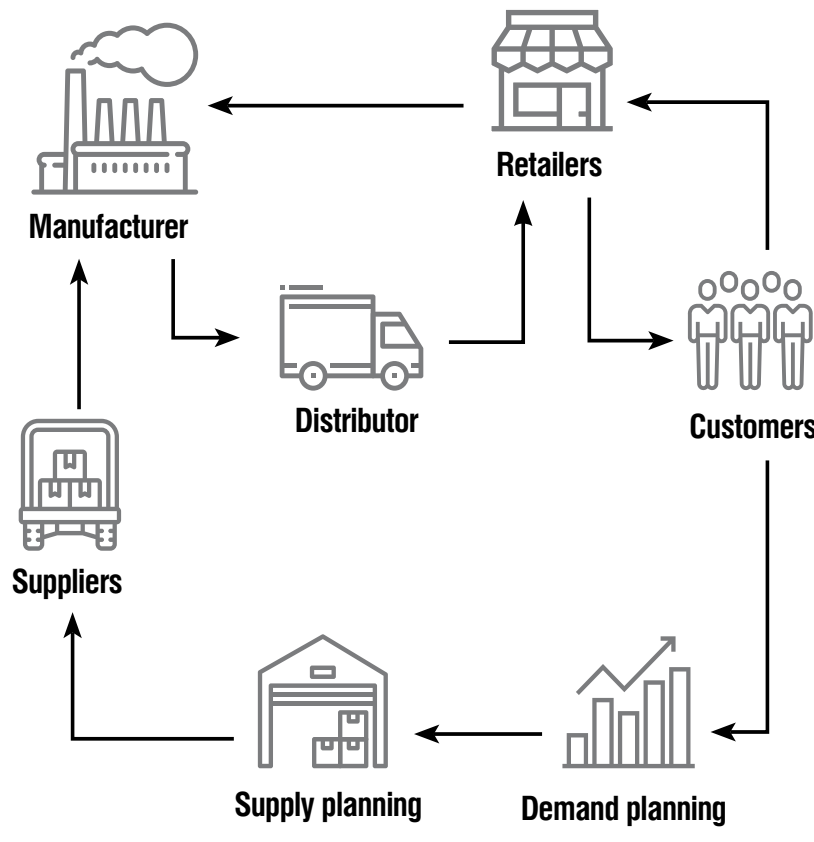

Fig. 4. FMCG supply chain

very helpful in using them. Although gadgets and systems are physically available, IoT applications reinforce gadget communication together as well as gadget and human communication in a robust way. IoT applications in the context of gadgets should ensure that information is accessed and tracked appropriately. For example, transportation and coordination programs that show the status of goods shipped (for example organic products, meat and dairy or even medicine). For proper transportation, the status of raw materials as well as products such as temperature, humidity, etc. will be checked and appropriate solutions to reduce the amount of waste as well as reducing air pollution are also adopted. IoT devices can enhance supply chain capability in terms of sustainability as well as greenness (such as green transportation and cold and green storage) [97] and there are, of course, many obstacles in this way for the supply chain [98]. Innovative developments, communications and IoT capabilities are on the rise and are increasingly open and flexible, so this makes the use of IoT be a welcome addition. IoT supply chain gadgets generate huge amounts of data that need to be collected and phased in to provide information about the status, area, usefulness and status of items and management. Therefore, intelligent information regulation enables powerful sensors and gadgets to use specific data and can be used to collect and decode data. These data are very big and therefore have their own way of analysis. In the following, big data is described as one of the capabilities and outputs of IoT.

\subsection{Big data in the FMCG supply chain}

Big data generation in industrial IoT (IIoT) is evident due to the widespread deployment of IoT sensors and devices. However, processing big data is challenging due to the limited computing, networking and storage resources at the end of the IoT device [99]. The FMCG industry supply chain is a changing organizational system that encompasses individuals, information, activities and resources in the manufacturing and production, processing and distribution of products from raw material supplier to consumer [100]. Big data is used in the production, packaging, sales and consumption of products. Figure 5 shows the big data rotation network in the FMCG supply chain. In the supply chain (as presented by Figure 4) manufacturers track large volumes of useful data to gain a better understanding of customers' desired values, then process that data and enter them in new product design cycles to optimize production. Retailers can use this big data to categorize and differentiate customer types and use this information for accurate sales plan, timely marketing, and customer loyalty develop-

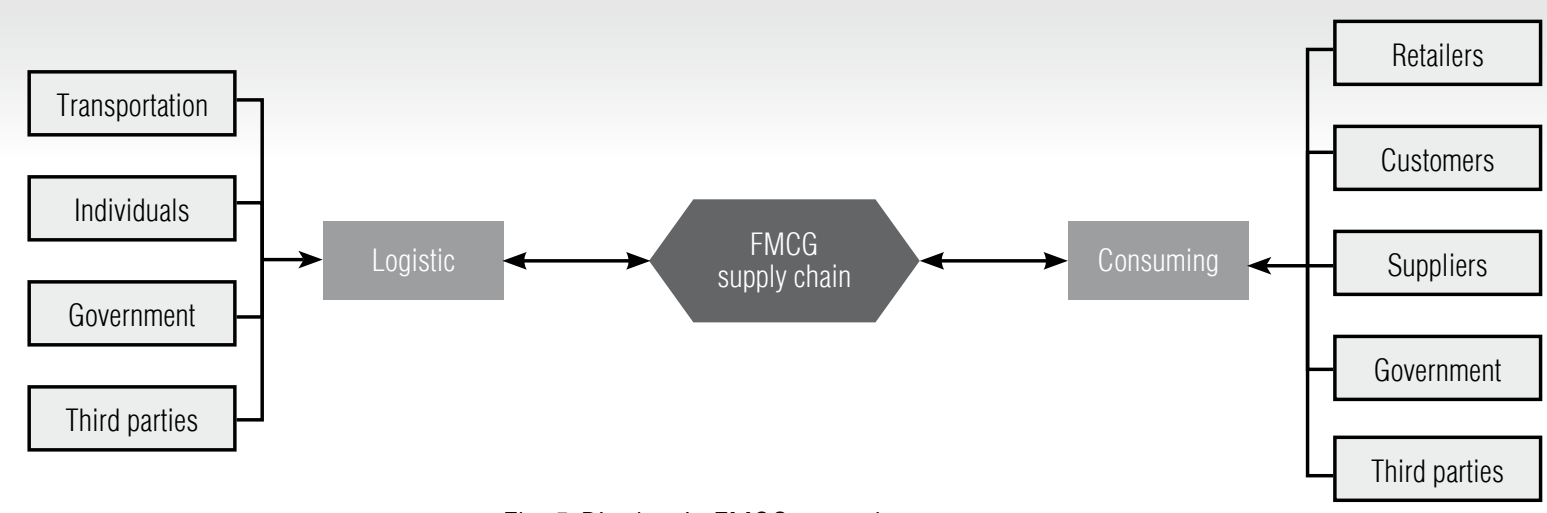

Fig. 5. Big data in FMCG network 
ment. By the generated data, customers can also make more precise decisions to buy products. It should be noted that every year hundreds of billions value are generated by big data in the FMCG supply chain and that illustrates the importance of big data in this industry.

Logistical data is provided by distribution activities and people involved in processes as well as government information. But one of the most important benefits of using big data for the FMCG industry is that it can be used to enhance the ability of distributors and the timely delivery of goods and products to customers. In addition, companies can optimize many of their activities using this data and consequently they gain a better understanding of the decision-making in the organization and make decisions more powerfully and transparently. In general, the following can be cited as the reasons for the importance of using and utilizing big data in the organization's supply chain [101]:

$\checkmark$ Performance optimization and improvement: If big data extracted from different parts of a supply chain is properly processed and analyzed, it can be one of the most important components of performance improvement in organizations.

- Transparency: Continuously receiving data from different parts of the supply chain can increase the transparency of the system and thus can reduce the possibility of errors in different parts.

- Increasing decision-making power: Using powerful algorithms to refine big data in the supply chain enables better understanding of the situation and can also increase decision-making power in the organization. By analyzing customer behavior using big data we can offer different marketing strategies for delivering products. In addition, business model structure can be changed to gain more market share.

\section{Sustainable smart supply chain framework}

In this section, we will develop a sustainable intelligent supply chain framework based on IoT and big data analytics. By studying the literature, it can be seen that frameworks for building smart cities based on big data and even internet of things have been provided [102], but the specific framework for the smart supply chain as one of the most important organizational units or in a particular community has not yet been presented. The framework presented is based on findings from the literature review and thematic analysis along with conceptual and theoretical backgrounds. In this framework, a layered approach is used which, according to the scien- tific literature, is usually applied in system architectures and infrastructures in the field of intelligent systems. The purpose of this framework is to develop a smart supply chain information landscape with IoT applications and big data processing. In this context, big data Analytics is aimed at optimizing and supporting smart decisions related to control, optimization, automation, management and planning of supply chain systems as business operating processes. Supply chain systems must be managed using IoT and big data analytics (as a set of advanced technologies, and new applications). Supply chain systems provide large amounts of data as inputs for applications. The data is received at different sensors at different scales and speeds and is automatically stored in the data warehouse for large scale use. Therefore, these components include various sources of data in different types and sizes that must be stored, processed, analyzed, and shared in different operations, functions, and states. Big data applications include a variety of program enabled by IoT in relation to environmental sustainability in different parts of the supply chain. A program usually contains several solutions to the different subdivisions of each domain that depend on the type of environmental sustainability issue that each domain faces. Figure 6 shows the deployment of big data processing using IoT technologies implemented on the cloud in the field of sustainable supply chain systems. These technologies include sensors, data warehouses, data processing platform and cloud computing model. Sensor data for various parts of the supply chain (in FMCG industries), which have been collected, integrated and pre-processed, are used for automation, support and decision making in operations using data mining and machine learning techniques for modeling, pattern recognition and correlation creation.

This framework includes comprehensive computing, data processing systems and wireless network infrastructure, cloud computing, data processing, data analysis, and data modeling to discover useful knowledge. This helps supply chain management by utilizing the big data related to monitoring, control, automation, optimization and management of infrastructure, resources, facilities, services and networks. Some of the concepts used in the framework are described as follows.

Collecting, storing and processing of big data: Sensors are one of the key features of sustainable smart systems that rely on common approaches to computing including the IoT. Sensor data will be available in a variety of formats, including time and space labels, along with a variety of data mining techniques and data visualization techniques for data processing and displaying 


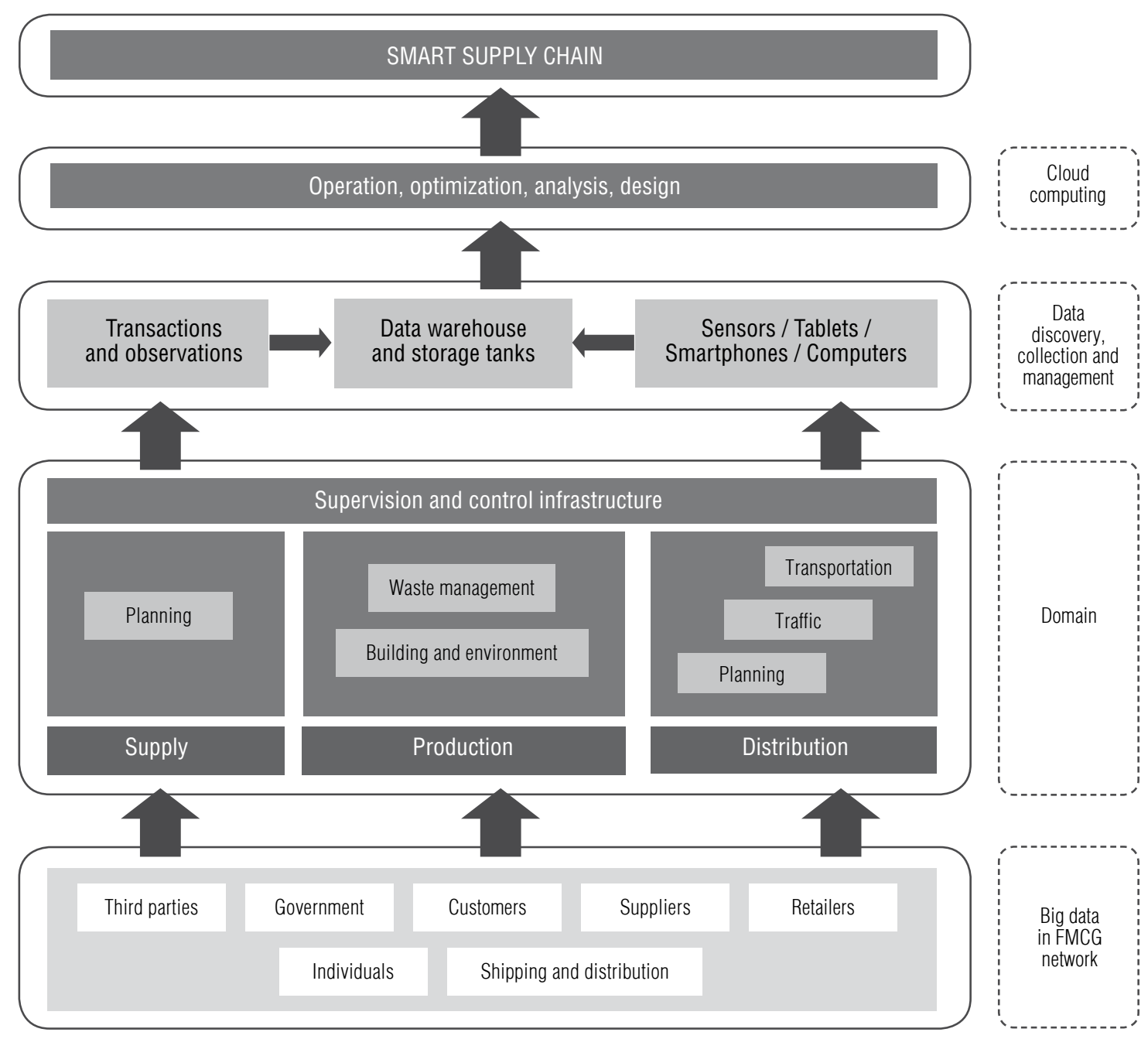

Fig. 6. Smart supply chain framework based on loT and big data analytics

interconnected patterns. But the end goal is to create a comprehensive system that supports data extraction, data integration, data processing, data evaluation, pattern exploration, pattern simulation and modeling, and deploying the results from the processes.

Cloud computing for big data processing: Cloud computing is a new processing method in which scalable and often virtualized resources are delivered as a processing service through communication networks such as local area networks and the internet. The focus of this model is on-demand service to the user, without the user having specific equipment to process or being aware of the place of processing. Cloud computing offers many solutions to the problems of sustainable smart systems by facilitating big data storage and providing the capabilities to process, manage and extract useful knowledge from them.
Intelligent logistics and transportation systems: Dynamic transportation is one of the key applications of IoT related to environmental sustainability. IoT plays an important role in improving the dynamics of all types of transportation in sustainable smart systems. Use of IoT includes automated tracking of distribution systems and vehicles, monitoring of road and traffic conditions for timely delivery and integrated safety mechanisms, and monitoring when distributing valuable goods. In general, the uses of IoT, as a form of pervasive computing are strongly affected by the dynamics of transportation in order to reduce energy consumption, reduce pollution, and eliminate inefficiencies.

Smart environment: IoT employs sensors to monitor and control mechanical and electronic systems used in industrial buildings. 
Infrastructure monitoring: IoT devices can be used to improve disaster management, improve emergency response coordination, improve service quality, and reduce operating costs in all infrastructure-related areas. As an ancillary product, IoT infrastructure enables efficient maintenance of planning activities by coordinating tasks between service providers and users of these infrastructures.

With the growing demand for IoT as well as the analysis of big data in smart systems, the use of these technologies also faces challenges. Some of these challenges include:

$\downarrow$ providing security for information;

$\downarrow$ lack of understanding of many features and information;

$\checkmark$ technical challenges;

$\checkmark$ the cost of many technologies;

$\uparrow$ quality assurance and data access;

So in addition to the positive and undeniable effects of using IoT and big data analytics, these challenges must also be addressed.

After the design, the framework was provided and approved by 24 supply chain specialists in FMCG companies. This study was tested using a five-point Likert scale questionnaire and the results showed the acceptability of this framework. It should be noted, however, that the selection of these experts was also challenging. Because these professionals had to be selected among those who had a thorough knowledge of IoT technologies and had a track record of using some of these technologies in their background.

\section{Conclusion}

IoT is a new form of pervasive computing and applications for big data that is increasingly being taken into account with operational performance and planning for sustainable development. Therefore, the use of IoT in the supply chain can greatly enhance its intelligence and thus improve its performance. On the other hand, analyzing big data and using it to realize key features of a smart and sustainable supply chain (such as operation and service efficiency, resource optimization, and intelligent infrastructure and facility management) has a huge impact. For this reason, the purpose of this paper was to review and integrate the related literature in order to identify and discuss IoT-based big data applications for supply chain sustainability. In this paper, the feasibility of developing smart supply chains using big data from IoT is explored to achieve the level of re- quired intelligence. In this paper, the supply chain of FMCG companies was selected. Products in these industries have a special nature and as a result their supply chain has different characteristics. Timely distribution and delivery system is one of the main features of this supply chain. The most important data-driven applications in these supply chains that are enabled through IoT include transportation, dynamics, energy, environment, infrastructure monitoring and management and supply chain planning. Therefore, expanding the intelligence landscape of the smart supply chain using sensor-based big data has great potential to promote environmental sustainability. To this end, a framework has been outlined that provides a lot of information on the smart supply chain.

This framework defines the scope of decisionmaking in the core parts of the supply chain in the FMCG industry according to their nature. With this framework, the ways in which big data can be accessed through the internet of things (which can itself be a path to sustainability and in some cases being green) are identified in this industry. By placing appropriate analytical tools in the computational parts of the framework (such as statistical analysis and optimization), one can gain a good understanding of the audience's beliefs. Finally, analyzing this data can help to make the organization more intelligent. One of the most important advantages of using this framework can be the production of optimal products based on customer preferences.

The implementation of the framework will always have challenges. One of the problems is always the use of huge volumes of data and therefore the high complexity of analysis. Since data is produced using the IoT technology without any restrictions, maintenance and computation on this data is very time consuming and complex and therefore there is a need for high knowledge in this field. In addition, IoT devices are not always available and can be costly to obtain. Therefore, all of these must always be considered when implementing the framework.

This framework provides the basis for developing research opportunities to integrate this type of supply chain as well as providing analytical insights into future research. This framework can be expanded and operational solutions in analytics and computing can be customized to suit the different industries. Also, providing computational solutions and incorporating them precisely into the framework can provide a clear pathway for solving new challenges. 


\section{References}

1. Evtodieva T.E., Chernova D.V., Ivanova N.V., Wirth J. (2020) The internet of things: Possibilities of application in intelligent supply chain management. Digital transformation of the economy: Challenges, trends and new opportunities. Series: Advances in Intelligent Systems and Computing, vol. 908 (S. Ashmarina, A. Mesquita, M. Vochozka, eds.). Cham: Springer, pp. 395-403. DOI: $10.1007 / 978-3-030-11367-438$.

2. Tajfar A.H., Gheysari M. (2016) Analysis the effects of internet of things technology in managing supply chain. International Journal of Information \& Communication Technology Research, vol. 8, no 3, pp. 15-25.

3. Grossmann I.E. (2018) Optimization and management in manufacturing engineering: resource collaborative optimization and management through the internet of things. Optimization Methods and Software, vol. 34, no 1, pp. 220-223. DOI: $10.1080 / 10556788.2018 .1527332$.

4. Wazid M., Das A.K., Hussain R., Succi G., Rodrigues J.J.P.C. (2019) Authentication in cloud-driven IoT-based big data environment: Survey and outlook. Journal of Systems Architecture, vol. 97, pp. 185-196. DOI: 10.1016/j.sysarc.2018.12.005.

5. Bibri S.E. (2015) The shaping of ambient intelligence and the internet of things: Historicoepistemic, socio-cultural, politico-institutional and eco-environmental dimensions. Atlantis Press. DOI: 10.2991/978-94-6239-142-0.

6. Bibri S.E., Krogstie J. (2016) On the social shaping dimensions of smart sustainable cities: A study in science, technology, and society. Sustainable Cities and Society, vol. 29, p. 219-246. DOI: 10.1016/j.scs.2016.11.004.

7. Muñuzuri J., Onieva L., Cortés P., Guadix J. (2020) Using IoT data and applications to improve port-based intermodal supply chains. Computers \& Industrial Engineering, vol. 139, article no 105668. DOI: 10.1016/J.CIE.2019.01.042.

8. Borah M.D., Naik V.B., Patgiri R., Bhargav A., Phukan B., Basani S.G.M. (2019) Supply chain management in agriculture using blockchain and IoT. Advanced applications of blockchain technology, Studies in big data, vol. 60 (S. Kim, G. Deka, eds). Singapore: Springer, pp. 227-241. DOI: 10.1007/978-981-13-8775-3_11.

9. Dai H.-N., Wang H., Hu G., Wan J., Imran M. (2020) Big data analytics for manufacturing internet of things: opportunities, challenges and enabling technologies. Enterprise Information Systems, vol. 14, no 9-10, pp. 1279-1303. DOI: 10.1080/17517575.2019.1633689.

10. Cox M., Ellsworth D. (1997) Application-controlled demand paging for out-of-core visualization. Proceedings of the 8th IEEE Visualization Conference (IEEE Vis 1997), Phoenix, AZ, USA, 19-24 October 1997, pp. 235-244. DOI: 10.1109/VISUAL.1997.663888.

11. Addo-Tenkorang R., Helo P.T. (2016) Big data applications in operations/supply-chain management: A literature review. Computers \& Industrial Engineering, vol. 101, pp. 528-543. DOI: 10.1016/j.cie.2016.09.023.

12. Manyika J., Chui M., Brown B., Bughin J., Dobbs R., Roxburgh C., Byers A.H. (2011) Big data: The next frontier for innovation, competition, and productivity. Available at: https://www.mckinsey.com/business-functions/mckinsey-digital/our-insights/big-data-thenext-frontier-for-innovation\# (accessed 15 December 2020).

13. Laney D. (2001) 3D data management: Controlling data volume, velocity, and variety. Technical report. META Group.

14. Russom P. (2011) Big data analytics. TDWI best pracrice report, 4th quarter. Renton, WA: TWDI.

15. Kwon O., Sim J.M. (2013) Effects of data set features on the performances of classification algorithms. Expert Systems with Applications, vol. 40, no 5, pp. 1847-1857. DOI: 10.1016/j.eswa.2012.09.017.

16. McAfee A., Brynjolfsson E. (2012) Big data: the management revolution. Harvard Business Review, vol. 90, no 10, pp. 61-67.

17. Oracle (2013) Oracle: Big data for the enterprise. White paper. Redwood Shores, CA: Oracle Corp.

18. Wamba S.F., Akter S., Edwards A., Chopin G., Gnanzou D. (2015) How 'big data' can make big impact: Findings from a systematic review and a longitudinal case study. International Journal of Production Economics, vol. 165, pp. 234-246. DOI: $10.1016 / \mathrm{j} . \mathrm{ijpe} .2014 .12 .031$.

19. White M. (2012) Digital workplaces: Vision and reality. Business Information Review, vol. 29, no 4, pp. $205-214$. DOI: $10.1177 / 0266382112470412$.

20. IDC (2013) Big data in 2020. Available at: https://www.emc.com/leadership/digital-universe/2012iview/big-data-2020.htm (accessed 15 December 2020).

21. Boyd D., Crawford K. (2012) Critical questions for big data: Provocations for a cultural, technological, and scholarly phenomenon. Information, Communication \& Society, vol. 15, no 5, pp. 662-679. DOI: 10.1080/1369118X.2012.678878.

22. Chen H., Chiang R., Storey V. (2012) Business intelligence and analytics: From big data to big impact. MIS Quarterly, vol. 36, no 4, pp. 1165-1188. DOI: $10.2307 / 41703503$.

23. Dremel C., Herterich M., Wulf J., Brocke J. (2020) Actualizing big data analytics affordances: A revelatory case study. Information \& Management, vol. 57, no 1, article no 103121. DOI: 10.1016/j.im.2018.10.007.

24. Ghasemaghaei M. (2020) The role of positive and negative valence factors on the impact of bigness of data on big data analytics usage. International Journal of Information Management, vol. 50, pp. 395-404. DOI: 10.1016/J.IJINFOMGT.2018.12.011.

25. Mikalef P., Krogstie J., Pappas I., Pavlou P. (2020) Exploring the relationship between big data analytics capability and competitive performance: The mediating roles of dynamic and operational capabilities. Information \& Management, vol. 57, no 2, article no 103169. DOI: $10.1016 / \mathrm{j} . \mathrm{im} .2019 .05 .004$

26. Strawn G.O. (2012) Scientific research: How many paradigms? Educause Review, vol. 47, no 3, pp. 26-34.

27. Golchha N. (2015) Big data - The information revolution. International Journal of Applied Research, vol. 1, no 12, pp. 791-794.

28. Wamba S.F., Akter S. (2015) Big data analytics for supply chain management: A literature review and research agenda. Enterprise and Organizational Modeling and Simulation (EOMAS 2015) (J. Barjis, R. Pergl, E. Babkin, eds.). Lecture Notes in Business Information Processing, vol. 231, pp. 61-72. DOI: 10.1007/978-3-319-24626-0_5.

29. Mital R., Coughlin J., Canaday M. (2014) Using big data technologies and analytics to predict sensor anomalies. Proceedings of the Advanced Maui Optical and Space Surveillance Technologies Conference (AMOS 2014), Wailea, Maui, Hawaii, 15-18 September 2014 pp. 84.

30. Chen M., Mao S., Zhang Y., Leung V.C. (2014) Big data: Related technologies, challenges and future prospects. Springer. DOI: $10.1007 / 978-3-319-06245-7$.

31. Marjani M., Nasaruddin F., Gani A., Karim A., Hashem I.A.T., Siddiqa A., Yaqoob I. (2017) Big IoT data analytics: Architecture, opportunities, and open research challenges. IEEE Access, vol. 5, pp. 5247-5261.

32. Chen C.P., Zhang C.-Y. (2014) Data-intensive applications, challenges, techniques and technologies: A survey on big data. Information Sciences, vol. 275, pp. 314-347. DOI: 10.1016/j.ins.2014.01.015.

33. Pfaffl M.W. (2001) A new mathematical model for relative quantification in real-time RT-PCR. Nucleic Acids Research, vol. 29, no 9 , p. e45. DOI: 10.1093/nar/29.9.e45. 
34. Jourdan Z., Rainer P.K., Marshall T.E. (2008) Business intelligence: An analysis of the literature. Information Systems Management, vol. 25, no 2, pp. 121-131. DOI: 10.1080/10580530801941512.

35. Bifet A., Holmes G., Kirkby R., Pfahringer B. (2010) MOA: Massive online analysis. Journal of Machine Learning Research, no 11 , pp. 1601-1604.

36. Kang Y.-S., Park I.-H., Rhee J., Lee Y.-H. (2016) MongoDB-based repository design for IoT generated RFID/sensor big data. IEEE Sensors Journal, vol. 16, no 2, pp. 485-497. DOI: 10.1109/JSEN.2015.2483499.

37. Jiang L., Xu L.D., Cai H., Jiang Z., Bu F., Xu B. (2014) An IoT-oriented data storage framework in cloud computing platform. IEEE Transactions on Industrial Informatics, vol. 10, no 2, pp. 1443-1451. DOI: 10.1109/TII.2014.2306384.

38. O'Leary D.E. (2013) 'Big data', the 'internet of things' and the 'internet of signs'. Intelligent Systems in Accounting, Finance and Management, vol. 20, no 1, pp. 53-65. DOI: 10.1002/isaf.1336.

39. Hagstrom M. (2012) High-performance analytics fuels innovation and inclusive growth: use big data, hyperconnectivity and speed to intelligence to get true value in the digital economy. Journal of Advanced Analytics, no 2, pp. 3-4.

40. Kenny J. (2014) Big data can have big impact on supply chain management: The use of data analytics is underused in supply chain management to minimize risk exposure. InsideCounsel.

41. Vasan S. (2014) Impact of big data and analytics in supply chain execution. Supply Chain Digital. Available at: https://www. supplychaindigital.com/logistics-1/impact-big-data-and-analytics-supply-chain-execution (accessed 15 December 2020).

42. Heudecker N., Buytendijk F., Kart L. (2013) Survey analysis: Big data adoption in 2013 shows substance behind the hype. Available at: https://www.gartner.com/en/documents/2589121/survey-analysis-big-data-adoption-in-2013-shows-substanc (accessed 15 December 2020).

43. Kamble S., Gunasekaran A. (2018) Big data-driven supply chain performance measurement system: a review and framework for implementation. International Journal of Production Research, vol. 58, no 1, pp. 65-86. DOI: 10.1080/00207543.2019.1630770.

44. Dubey R., Gunasekaran A., Childe S.J. (2019) Big data analytics capability in supply chain agility: The moderating effect of organizational flexibility. Management Decision, vol. 57, no 8, pp. 2092-2112. DOI: 10.1108/MD-01-2018-0119.

45. Mayer-Schönberger V., Cukier K. (2013) Big data: A revolution that will transform how we live, work, and think. New York: Eamon Dolan/ Mariner Book.

46. Rozados I.V., Tjahjono B. (2014) Big data analytics in supply chain management: Trends and related research. Proceedings of the 6 th International Conference on Operations and Supply Chain Management (OSCM), Sanur, Bali, 10-12 December 2014, pp. 1096-1107. DOI: $10.13140 /$ RG.2.1.4935.2563

47. Waller M.A., Fawcett S.E. (2013) Data science, predictive analytics, and big data: A revolution that will transform supply chain design and management. Journal of Business Logistics, vol. 34, no 2, pp. 77-84. DOI: 10.1111/jbl.12010.

48. Bates D.W., Saria S., Ohno-Machado L., Shah A., Escobar G. (2014) Big data in health care: using analytics to identify and manage highrisk and high-cost patients. Health Affairs, vol. 33, no 7, pp. 1123-1131. DOI: 10.1377/hlthaff.2014.0041.

49. Hopkins J. (2016) A comparative study examining academic cohorts with transnational migratory intentions towards Canada and Australia. Higher Education Quarterly, vol. 70, no 3, pp. 246-263. DOI: 10.1111/hequ.12091.

50. Kim G.-H., Trimi S., Chung J.-H. (2014) Big-data applications in the government sector. Communications of the ACM, vol. 57, no 3 , pp. 78-85. DOI: $10.1145 / 2500873$.

51. Sellitto C., Hawking P. (2015) Enterprise systems and data analytics: A fantasy football case study. International Journal of Enterprise Information Systems, vol. 11, no 3, pp. 1-12.

52. Hopkins J., Hawking P. (2017) Big data analytics and IoT in logistics: a case study. International Journal of Logistics Management, vol. 29, no 2, pp. 575-591. DOI: 10.1108/IJLM-05-2017-0109.

53. Sarma S., Brock D.L., Ashton K. (2000) The networked physical world: Proposals for engineering the next generation of computing, commerce \& automatic-identification. White paper. Available at: https://cocoa.ethz.ch/downloads/2014/06/None_MIT-AUTOID-WH-001.pdf (accessed 15 December 2020).

54. Greengard S. (2015) The internet of things. Cambridge, MA: MIT Press.

55. Xu L.D., He W., Li S. (2014) Internet of things in industries: A survey. IEEE Transactions on Industrial Informatics, vol. 10, no 4, pp. 2233-2243. DOI: 10.1109/TII.2014.2300753.

56. Ben-Daya M., Hassini E., Bahroun Z. (2019) Internet of things and supply chain management:a literature review. International Journal of Production Research, vol. 57, no 15-16, pp. 4719-4742. DOI: 10.1080/00207543.2017.1402140.

57. Atzori L., Iera A., Morabito G. (2010) The internet of things: A survey. Computer Networks, vol. 54, no 15, pp. 2787-2805. DOI: 10.1016/j.comnet.2010.05.010.

58. Gubbi J., Buyya R., Marusic S., Palaniswami M. (2013) Internet of things (IoT): A vision, architectural elements, and future directions. Future Generation Computer Systems, vol. 29, no 7, pp. 1645-1660. DOI: 10.1016/j.future.2013.01.010.

59. Leminen S., Rajahonka M., Wendelin R., Westerlund M. (2020) Industrial internet of things business models in the machine-to-machine context. Industrial Marketing Management, vol. 84, pp. 298-311. DOI: 10.1016/j.indmarman.2019.08.008.

60. Zhou K., Liu T., Zhou L. (2015) Industry 4.0: Towards future industrial opportunities and challenges. Proceedings of the 12th International Conference on Fuzzy Systems and Knowledge Discovery (FSKD 2015), Zhangiiajie, China, 15-17 August 2015, pp. 2147-2152. DOI: 10.1109/FSKD.2015.7382284.

61. Li L. (2011) Application of the internet of thing in green agricultural products supply chain management. Proceedings of the 2011 Fourth International Conference on Intelligent Computation Technology and Automation (ICICTA), Shenzhen, China, 28-29 March 2011, vol. 1, pp. 1022-1025. DOI: 10.1109/ICICTA.2011.256.

62. Kopetz H. (2011) Real-time systems. Design principles for distributed embedded applications. Springer.

63. Xia F., Yang L., Wang L., Vinel A. (2012) Internet of things. International Journal of Communication Systems, vol. 25, no 9, pp. 1101-1102. DOI: $10.1002 /$ dac.2417.

64. Wortmann F., Flüchter K. (2015) Internet of things. Business \& Information Systems Engineering, vol. 57, no 3, pp. 221-224. DOI: $10.1007 / \mathrm{s} 12599-015-0383-3$.

65. Postcapes (2017) IoT standards and protocols. Available at: https://www.postscapes.com/internet-of-thingsprotocols/ (accessed 15 September 2020).

66. Lee I., Lee K. (2015) The internet of things (IoT): Applications, investments, and challenges for enterprises. Business Horizons, vol. 58, no 4, pp. 431-440. DOI: 10.1016/j.bushor.2015.03.008

67. Zeinab K.A.M., Elmustafa S.A.A. (2017) Internet of things applications, challenges and related future technologies. World Scientific News, vol. 67 , no 2 , pp. 126-148. 
68. Davies R. (2015) The internet of things opportunities and challenges. Available at: https://epthinktank.eu/2015/05/21/the-internet-ofthings-opportunities-and-challenges/ (accessed 15 December 2020).

69. Porter M.E., Heppelmann J.E. (2014) How smart, connected products are transforming competition. Harvard Business Review, vol. 92 , pp. 11-64.

70. Uckelmann D., Harrison M., Michahelles F. (2011) An architectural approach towards the future internet of things. Architecting the internet of things. Berlin, Heidelberg: Springer. DOI: 10.1007/978-3-642-19157-2_1.

71. Sun C. (2012) Application of RFID technology for logistics on internet of things. AASRI Procedia, vol. 1, pp. 106-111. DOI: $10.1016 /$ j.aasri.2012.06.019.

72. Bandyopadhyay D., Sen J. (2011) Internet of things applications, challenges and related future technologies. Wireless Personal Communications, no 58, pp. 49-69. DOI: 10.1007/s11277-011-0288-5.

73. Langley D.L., van Doorn J., Ng I.C.L., Stieglitz S., Lazovik A., Boonstra A. (2020) The internet of everything: Smart things and their impact on business models. Journal of Business Research, vol. 122, pp. 853-863. DOI: 10.1016/j.jbusres.2019.12.035.

74. Yuvaraj S., Sangeetha M. (2016) Smart supply chain management using internet of things (IoT) and low power wireless communication systems. Proceedings of the IEEE 2016 International Conference on Wireless Communications, Signal Processing and Networking (WiSPNET), Chennai, India, 23-25 March 2016, pp. 555-558. DOI: 10.1109/WiSPNET.2016.7566196.

75. Tao F., Ying Z., Xu L.D., Zhang L. (2014) IoT-based intelligent perception and access of manufacturing resource toward cloud manufacturing. IEEE Transactions on Industrial Informatics, vol. 10, no 2, pp. 1547-1557. DOI: 10.1109/TII.2014.2306397.

76. Gnimpieba Z.D.R., Nait-Sidi-Moh A., Durand D., Fortin J. (2015) Using internet of things technologies for a collaborative supply chain Application to tracking of pallets and containers. Procedia Computer Science, vol. 56, pp. 550-557. DOI: 10.1016/j.procs.2015.07.251.

77. Verdouw C.N., Robbemond R.M., Verwaart T., Wolfert J., Beulens A.J.M. (2018) A reference architecture for IoTbased logistic information systems in agri-food supply chains. Enterprise Information Systems, vol. 12, no 7, pp. 755-779. DOI: $10.1080 / 17517575.2015 .1072643$.

78. Decker C., et al. (2008) Cost-benefit model for smart items in the supply chain. The internet of things (C. Floerkemeier, M. Langheinrich, E. Fleisch, F. Mattern, S.E. Sarma, eds.). Lecture Notes in Computer Science, vol. 4952, pp. 155-172. DOI: 10.1007/978-3-540-78731-0 10.

79. Xu L.D. (2011) Information architecture for supply chain quality management. International Journal of Production Research, vol. 49, no 1 , pp. 183-198. DOI: 10.1080/00207543.2010.508944.

80. Chen R.-Y. (2015) Intelligent IoT-enabled system in green supply chain using integrated FCM method. International Journal of Business Analytics, vol. 2, no 3, pp. 47-66. DOI: 10.4018/IJBAN.2015070104.

81. Yan J., Xin S., Liu Q., Xu W., Yang L., Fan L., Chen B., Wang Q. (2014) Intelligent supply chain integration and management based on cloud of things. International Journal of Distributed Sensor Networks, vol. 10, no 3, article no 624839. DOI: 10.1155/2014/624839.

82. Parry G.C., Brax S.A., Maull R.S., Ng I.C.L. (2016) Operationalising IoT for reverse supply: the development of use-visibility measures. Supply Chain Management, vol. 21, no 2, pp. 228-244. DOI: 10.1108/SCM-10-2015-0386.

83. Thoben K.D., Wiesner S., Wuest T. (2017) "Industrie 4.0" and smart manufacturing - A review of research issues and application examples. International Journal of Automation Technology, vol. 11, no 1, pp. 4-16.

84. Fleisch E. (2010) What is the internet of things? An economic perspective, business process and applications. White Paper WP-BIZAPP-053. Available at: https://cocoa.ethz.ch/downloads/2014/06/None_AUTOIDLABS-WP-BIZAPP-53.pdf (accessed 15 December 2020).

85. Abdel-Basset M., Nabeeh N.A., El-Ghareeb H.A., Aboelfetouh A. (2020) Utilising neutrosophic theory to solve transition difficulties of IoT-based enterprises. Enterprise Information Systems, vol. 14, no 9-10, pp. 1304-1324. DOI: 10.1080/17517575.2019.1633690.

86. Gonzalez J. (2011) The impact of the internet of things on business and society. Foundation de la Innovation Bankinter.

87. Poirier C.C., Bauer M.J. (2000) E-supply chain: Using the internet to revolutionize your business. San Francisco: Berrett-Koehler.

88. Vervest P., Preiss K., van Heck E., Pau L.-F. (2004) The emergence of smart business networks. Journal of Information Technology, vol. 19, no 4, pp. 228-233. DOI: 10.1057/palgrave.jit.2000024.

89. Wirtz B.W., Weyerer J.C., Schichtel F.T. (2019) An integrative public IoT framework for smart government. Government Information Quarterly, vol. 36, no 2, pp. 333-345. DOI: 10.1016/j.giq.2018.07.001.

90. Janssen M., Luthra S., Mangla S, Rana N.P., Dwivedi Y.K. (2019) Challenges for adopting and implementing IoT in smart cities: An integrated MICMAC-ISM approach. Internet Research, vol. 29, no 6, pp. 1589-1616. DOI: 10.1108/INTR-06-2018-0252.

91. Abdel-Basset M., Manogaran G., Mohamed M. (2018) Internet of things (IoT) and its impact on supply chain: A framework for building smart, secure and efficient systems. Future Generation Computer Systems, vol. 86, pp. 614-628. DOI: 10.1016/j.future.2018.04.051.

92. Rong K., Hu G., Lin Y., Shi Y., Guo L. (2015) Understanding business ecosystem using a 6C framework in Internet-of-Things-based sectors. International Journal of Production Economics, vol. 159, pp. 41-55. DOI: 10.1016/j.ijpe.2014.09.003.

93. Cegielski C.G., Jones Farmer L.A., Wu Y., Hazen B.T. (2012) Adoption of cloud computing technologies in supply chains. International Journal of Logistics Management, vol. 32, no 2, pp. 184-211. DOI: 10.1108/09574091211265350.

94. Suguna S.K., Kumar S.N. (2019) Application of cloud computing and internet of things to improve supply chain processes. Edge computing: From hype to reality. Springer, pp. 145-170.

95. Arlbjorn J.S., de Haas H.D., Munksgaard K.B. (2011) Exploring supply chain innovation. Logistics Research, vol. 3, no 1, pp. 3-18. DOI: $10.1007 / \mathrm{s} 12159-010-0044-3$.

96. Lee I. (2015) The Internet of Things (IoT) for supply chain innovation: a conceptual framework and analysis of Fortune 200 companies. Asia Pacific Journal of Innovation and Entrepreneurship, vol. 9, no 1, pp. 81-103.

97. Nozari H., Najafi E., Fallah M., Lotfi F.H. (2019) Quantitative analysis of key performance indicators of green supply chain in FMCG industries using non-linear fuzzy method. Mathematics, vol. 7, no 11, article no 1020. DOI: 10.3390/math7111020.

98. Kaur J., Sidhu R., Awasthi A., Srivastava S.K. (2019) A Pareto investigation on critical barriers in green supply chain management. International Journal of Management Science and Engineering Management, vol. 14, no 2, pp. 113-123. DOI: 10.1080/17509653.2018.1504237.

99. Rehman M.H., Yaqoob I., Salah K., Imran M., Jayaraman P.P., Perera C. (2019) The role of big data analytics in industrial Internet of Things. Future Generation Computer Systems, no 99, pp. 247-259. DOI: 10.1016/j.future.2019.04.020.

100. Yu M., Nagurney A. (2013) Competitive food supply chain networks with application to fresh produce. European Journal of Operational Research, vol. 224, no 2, pp. 273-282. DOI: 10.1016/j.ejor.2012.07.033.

101. Ji G., Hu L., Tan K.H. (2017) A study on decision-making of food supply chain based on big data. Journal of Systems Science and Systems Engineering, no 26, pp. 183-198. DOI: 10.1007/s11518-016-5320-6.

102. Osman A.M.S. (2019) A novel big data analytics framework for smart cities. Future Generation Computer Systems, no 91, pp. 620-633. 


\section{About the authors}

\section{Hamed Nozari}

Ph.D.;

Lecturer, Department of Industrial Engineering, Islamic Azad University, Central Tehran Branch, Hamila Blvd., Poonak Sqr., Tehran 1469669191, Iran;

E-mail: Ham.nozari.eng@iauctb.ac.ir

ORCID: 0000-0002-6500-6708

\section{Mohammad Fallah}

Ph.D.;

Associated Professor, Department of Industrial Engineering, Islamic Azad University, Central Tehran Branch, Hamila Blvd., Poonak Sqr., Tehran 1469669191, Iran;

E-mail: Mohammad.fallah43@yahoo.com

ORCID: 0000-0001-5541-4284

\section{Hamed Kazemipoor}

Ph.D.;

Assistant Professor, Department of Industrial Engineering, Islamic Azad University, Central Tehran Branch, Hamila Blvd., Poonak Sqr., Tehran, 1469669191 Iran;

E-mail: Hkazemipoor@yahoo.com

ORCID: 0000-0002-1848-8927

\section{Seyed Esmaeil Najafi}

Ph.D.;

Assistant Professor, Department of Industrial Engineering, Islamic Azad University, Science and Research Branch, Daneshgah Blvd., Simon Bulivar Blvd., Tehran 1477893855, Iran;

E-mail: E.najafi@srbiau.ac.ir

ORCID: 0000-0002-3125-4439

\section{Анализ больших данных в управлении цепями поставок на основе интернета вещей в отраслях FMCG}

\section{X. Нозари ${ }^{\mathrm{a}}$}

E-mail: Ham.nozari.eng@iauctb.ac.ir

\section{М. Фаллах ${ }^{\mathrm{a}}$}

E-mail: Mohammad.fallah43@yahoo.com

\section{X. Каземипур ${ }^{a}$}

E-mail: Hkazemipoor@yahoo.com

\section{С.Э. Найяфи}

E-mail: E.najafi@srbiau.ac.ir

a Islamic Azad University, Central Tehran Branch Адрес: Hamila Blvd., Poonak Sqr., Tehran 1469669191, Iran

b Islamic Azad University, Tehran Branch, Science and Research Адрес: Daneshgah Blvd., Simon Bulivar Blvd., Tehran 1477893855, Iran 


\section{Аннотация}

Цепи поставок являются одним из наиболее существенных элементов производственных систем и промышленных компаний, и их «умные» характеристики помогают бизнесу стать интеллектуальным. Поэтому использование инновационных технологий, направленных на повышение бизнес-интеллекта, представляет собой актуальную задачу. «Умная» цепь поставок использует инновационные инструменты для повышения качества, увеличения производительности и облегчения процесса принятия решений. Интернет вещей (internet of things, IoT) является одним из ключевых элементов ИТ-инфраструктуры для развития интеллектуальных цепей поставок, обладающих высоким потенциалом для обеспечения устойчивости производственных систем. Кроме того, интернет вещей является одним из важнейших источников больших данных. Большие данные и стратегии анализа данных, предоставляющие широкие возможности для оптимизации решений и повышения производительности, в настоящее время быстро развиваются. В связи с этим в данной статье предпринята попытка рассмотреть информативные стратегии развития цепей поставок (на основе частного случая - цепей поставок в отраслях FMCG), а также разработать аналитический подход к построению устойчивых «умных» цепей поставок с использованием анализа больших данных на основе интернета вещей. Предлагаемый подход основан на методологии внедрения интернета вещей, с акцентом на использование исходных больших данных и экспертных оценок. Учитывая характер индустрии FMCG, это может привести к существенным улучшениям в области производственных решений.

Ключевые слова: большие данные; интернет вещей; управлении цепями поставок на основе интернета вещей; цепи поставок отраслей FMCG.

Цитирование: Nozari H., Fallah M., Kazemipoor H., Najafi S.E. Big data analysis of IoT-based supply chain management considering FMCG industries // Business Informatics. 2021. Vol. 15. No 1. P. 78-96.

DOI: 10.17323/2587-814X.2021.1.78.96

\section{Литература}

1. Evtodieva T.E., Chernova D.V., Ivanova N.V., Wirth J. The internet of things: Possibilities of application in intelligent supply chain management // Digital transformation of the economy: Challenges, trends and new opportunities. Series: Advances in Intelligent Systems and Computing. Vol. 908 (S. Ashmarina, A. Mesquita, M. Vochozka, eds.). Cham: Springer, 2020. P. 395-403. DOI: $10.1007 / 978-3-030-11367-4 \_38$.

2. Tajfar A.H., Gheysari M. Analysis the effects of internet of things technology in managing supply chain // International Journal of Information \& Communication Technology Research. 2016. Vol. 8. No 3. P. 15-25.

3. Grossmann I.E. Optimization and management in manufacturing engineering: resource collaborative optimization and management through the internet of things // Optimization Methods and Software. 2018. Vol. 34. No 1. P. 220-223. DOI: $10.1080 / 10556788.2018 .1527332$.

4. Authentication in cloud-driven IoT-based big data environment: Survey and outlook / M. Wazid [et al.] // Journal of Systems Architecture. 2019. Vol. 97. P. 185-196. DOI: 10.1016/j.sysarc.2018.12.005.

5. Bibri S.E. The shaping of ambient intelligence and the internet of things: Historicoepistemic, socio-cultural, politico-institutional and eco-environmental dimensions. Atlantis Press, 2015. DOI: 10.2991/978-94-6239-142-0.

6. Bibri S.E., Krogstie J. On the social shaping dimensions of smart sustainable cities: A study in science, technology, and society // Sustainable Cities and Society. 2016. Vol. 29. P. 219-246. DOI: 10.1016/j.scs.2016.11.004.

7. Muñuzuri J., Onieva L., Cortés P., Guadix J. Using IoT data and applications to improve port-based intermodal supply chains // Computers \& Industrial Engineering. 2020. Vol. 139. Article no 105668. DOI: 10.1016/J.CIE.2019.01.042.

8. Supply chain management in agriculture using blockchain and IoT / M.D. Borah [et al.] // Advanced applications of blockchain technology, Studies in big data. Vol. 60 (S. Kim, G. Deka, eds). Singapore: Springer, 2019. P. 227-241. DOI: 10.1007/978-981-13-8775-3_11.

9. Big data analytics for manufacturing internet of things: opportunities, challenges and enabling technologies / H.-N. Dai [et al.] // Enterprise Information Systems. 2020. Vol. 14. No 9-10. P. 1279-1303. DOI: 10.1080/17517575.2019.1633689.

10. Cox M., Ellsworth D. Application-controlled demand paging for out-of-core visualization // Proceedings of the 8th IEEE Visualization Conference (IEEE Vis 1997). Phoenix, AZ, USA, 19-24 October 1997. P. 235-244. DOI: 10.1109/VISUAL.1997.663888.

11. Addo-Tenkorang R., Helo P.T. Big data applications in operations/supply-chain management: A literature review // Computers \& Industrial Engineering. 2016. Vol. 101. P. 528-543. DOI: 10.1016/j.cie.2016.09.023.

12. Big data: The next frontier for innovation, competition, and productivity / J. Manyika [et al.], 2011. [Электронный pecyрc]: https://www.mckinsey.com/business-functions/mckinsey-digital/our-insights/big-data-the-next-frontier-for-innovation\# (дата обращения 15.12.2020).

13. Laney D. 3D data management: Controlling data volume, velocity, and variety. Technical report. META Group, 2001.

14. Russom P. Big data analytics. TDWI best pracrice report, 4th quarter. Renton, WA: TWDI, 2011.

15. Kwon O., Sim J.M. Effects of data set features on the performances of classification algorithms // Expert Systems with Applications. 2013. Vol. 40. No 5. P. 1847-1857. DOI: 10.1016/j.eswa.2012.09.017.

16. McAfee A., Brynjolfsson E. Big data: the management revolution // Harvard Business Review. 2012. Vol. 90. No 10. P. 61-67.

17. Oracle: Big data for the enterprise. White paper. Redwood Shores, CA: Oracle Corp., 2013.

18. How 'big data' can make big impact: Findings from a systematic review and a longitudinal case study / S.F. Wamba [et al.] // International Journal of Production Economics. 2015. Vol. 165. P. 234-246. DOI: 10.1016/j.ijpe.2014.12.031. 
19. White M. Digital workplaces: Vision and reality // Business Information Review. 2012. Vol. 29. No 4. P. 205-214. DOI: $10.1177 / 0266382112470412$.

20. Big data in 2020 / IDC, 2013). [Электронный ресурc]: https://www.emc.com/leadership/digital-universe/2012iview/big-data-2020.htm (дата обращения 15.12.2020).

21. Boyd D., Crawford K. Critical questions for big data: Provocations for a cultural, technological, and scholarly phenomenon // Information, Communication \& Society. 2012. Vol. 15. No 5. P. 662-679. DOI: 10.1080/1369118X.2012.678878.

22. Chen H., Chiang R., Storey V. Business intelligence and analytics: From big data to big impact // MIS Quarterly. 2012. Vol. 36. No 4. P. 1165-1188. DOI: $10.2307 / 41703503$.

23. Dremel C., Herterich M., Wulf J., Brocke J. Actualizing big data analytics affordances: A revelatory case study // Information \& Management. 2020. Vol. 57. No 1. Article no 103121. DOI: 10.1016/j.im.2018.10.007.

24. Ghasemaghaei M. The role of positive and negative valence factors on the impact of bigness of data on big data analytics usage // International Journal of Information Management. 2020. Vol. 50. P. 395-404. DOI: 10.1016/J.IJINFOMGT.2018.12.011.

25. Mikalef P., Krogstie J., Pappas I., Pavlou P. Exploring the relationship between big data analytics capability and competitive performance: The mediating roles of dynamic and operational capabilities // Information \& Management. 2020. Vol. 57. No 2. Article no 103169. DOI: $10.1016 /$ j.im.2019.05.004.

26. Strawn G.O. Scientific research: How many paradigms? // Educause Review. 2012. Vol. 47. No 3. P. 26-34

27. Golchha N. Big data - The information revolution // International Journal of Applied Research. 2015. Vol. 1. No 12. P. 791-794.

28. Wamba S.F., Akter S. Big data analytics for supply chain management: A literature review and research agenda // Enterprise and Organizational Modeling and Simulation (EOMAS 2015) (J. Barjis, R. Pergl, E. Babkin, eds.). Lecture Notes in Business Information Processing. 2015. Vol. 231. P. 61-72. DOI: 10.1007/978-3-319-24626-0_5.

29. Mital R., Coughlin J., Canaday M. Using big data technologies and analytics to predict sensor anomalies // Proceedings of the Advanced Maui Optical and Space Surveillance Technologies Conference (AMOS 2014). Wailea, Maui, Hawaii, 15-18 September 2014. P. 84.

30. Chen M., Mao S., Zhang Y., Leung V.C. Big data: Related technologies, challenges and future prospects. Springer, 2014. DOI: $10.1007 / 978-3-319-06245-7$.

31. Big IoT data analytics: Architecture, opportunities, and open research challenges / M. Marjani [et al.] // IEEE Access. 2017. Vol. 5. P. $5247-5261$.

32. Chen C.P., Zhang C.-Y. Data-intensive applications, challenges, techniques and technologies: A survey on big data // Information Sciences. 2014. Vol. 275. P. 314-347. DOI: 10.1016/j.ins.2014.01.015.

33. Pfaffl M.W. A new mathematical model for relative quantification in real-time RT-PCR // Nucleic Acids Research. 2001. Vol. 29. No 9. P. e45. DOI: 10.1093/nar/29.9.e45.

34. Jourdan Z., Rainer P.K., Marshall T.E. Business intelligence: An analysis of the literature // Information Systems Management. 2008 Vol. 25. No 2. P. 121-131. DOI: 10.1080/10580530801941512.

35. Bifet A., Holmes G., Kirkby R., Pfahringer B. MOA: Massive online analysis // Journal of Machine Learning Research. 2010. No 11 . P. 1601-1604.

36. Kang Y.-S., Park I.-H., Rhee J., Lee Y.-H. MongoDB-based repository design for IoT generated RFID/sensor big data // IEEE Sensors Journal. 2016. Vol. 16. No 2. P. 485-497. DOI: 10.1109/JSEN.2015.2483499.

37. An IoT-oriented data storage framework in cloud computing platform / L. Jiang [et al.] // IEEE Transactions on Industrial Informatics. 2014 Vol. 10. No 2. P. 1443-1451. DOI: 10.1109/TII.2014.2306384.

38. O'Leary D.E. 'Big data', the 'internet of things' and the 'internet of signs' // Intelligent Systems in Accounting, Finance and Management. 2013. Vol. 20. No 1. P. 53-65. DOI: 10.1002/isaf.1336.

39. Hagstrom M. High-performance analytics fuels innovation and inclusive growth: use big data, hyperconnectivity and speed to intelligence to get true value in the digital economy // Journal of Advanced Analytics. 2012. No 2. P. 3-4.

40. Kenny J. Big data can have big impact on supply chain management: The use of data analytics is underused in supply chain management to minimize risk exposure. InsideCounsel, 2014.

41. Vasan S. Impact of big data and analytics in supply chain execution. Supply Chain Digital / 2014. [Электронный pecypc]: https://www.supplychaindigital.com/logistics-1/impact-big-data-and-analytics-supply-chain-execution (дата обращения 15.12.2020).

42. Heudecker N., Buytendijk F., Kart L. Survey analysis: Big data adoption in 2013 shows substance behind the hype / 2013. [Электронный pecypc]: https://www.gartner.com/en/documents/2589121/survey-analysis-big-data-adoption-in-2013-shows-substanc (дата обращения 15.12.2020)

43. Kamble S., Gunasekaran A. Big data-driven supply chain performance measurement system: a review and framework for implementation // International Journal of Production Research. 2018. Vol. 58. No 1. P. 65-86. DOI: 10.1080/00207543.2019.1630770.

44 Dubey R., Gunasekaran A., Childe S.J. Big data analytics capability in supply chain agility: The moderating effect of organizational flexibility // Management Decision. 2019. Vol. 57. No 8. P. 2092-2112. DOI: 10.1108/MD-01-2018-0119.

45. Mayer-Schönberger V., Cukier K. Big data: A revolution that will transform how we live, work, and think. New York: Eamon Dolan/Mariner Book, 2013.

46. Rozados I.V., Tjahjono B. Big data analytics in supply chain management: Trends and related research // Proceedings of the 6th International Conference on Operations and Supply Chain Management (OSCM). Sanur, Bali, 10-12 December 2014. P. 1096-1107. DOI: $10.13140 /$ RG.2.1.4935.2563

47. Waller M.A., Fawcett S.E. Data science, predictive analytics, and big data: A revolution that will transform supply chain design and management // Journal of Business Logistics. 2013. Vol. 34. No 2. P. 77-84. DOI: 10.1111/jbl.12010.

48. Big data in health care: using analytics to identify and manage high-risk and high-cost patients / D.W. Bates [et al.] // Health Affairs. 2014. Vol. 33. No 7. P. 1123-1131. DOI: 10.1377/hlthaff.2014.0041.

49. Hopkins J. A comparative study examining academic cohorts with transnational migratory intentions towards Canada and Australia // Higher Education Quarterly. 2016. Vol. 70. No 3. P. 246-263. DOI: 10.1111/hequ.12091.

50. Kim G.-H., Trimi S., Chung J.-H. Big-data applications in the government sector // Communications of the ACM. 2014. Vol. 57. No 3. P. 78-85. DOI: $10.1145 / 2500873$.

51. Sellitto C., Hawking P. Enterprise systems and data analytics: A fantasy football case study // International Journal of Enterprise Information Systems. 2015. Vol. 11. No 3. P. 1-12.

52. Hopkins J., Hawking P. Big data analytics and IoT in logistics: a case study // International Journal of Logistics Management. 2017. Vol. 29. No 2. P. 575-591. DOI: 10.1108/IJLM-05-2017-0109. 
53. Sarma S., Brock D.L., Ashton K. The networked physical world: Proposals for engineering the next generation of computing, commerce \& automatic-identification. White paper, 2000. [Электронный ресурc]: https://cocoa.ethz.ch/downloads/2014/06/none_MIT-AUTOIDWH-001.pdf (дата обращения 15.12.2020).

54. Greengard S. The internet of things. Cambridge, MA: MIT Press, 2015.

55. Xu L.D., He W., Li S. Internet of things in industries: A survey // IEEE Transactions on Industrial Informatics. 2014. Vol. 10. No 4. P. 2233-2243. DOI: 10.1109/TII.2014.2300753.

56. Ben-Daya M., Hassini E., Bahroun Z. Internet of things and supply chain management:a literature review // International Journal of Production Research. 2019. Vol. 57. No 15-16. P. 4719-4742. DOI: 10.1080/00207543.2017.1402140.

57. Atzori L., Iera A., Morabito G. The internet of things: A survey // Computer Networks. 2010. Vol. 54. No 15. P. 2787-2805. DOI: $10.1016 /$ j.comnet.2010.05.010.

58. Gubbi J., Buyya R., Marusic S., Palaniswami M. Internet of things (IoT): A vision, architectural elements, and future directions // Future Generation Computer Systems. 2013. Vol. 29. No 7. P. 1645-1660. DOI: 10.1016/j.future.2013.01.010.

59. Leminen S., Rajahonka M., Wendelin R., Westerlund M. Industrial internet of things business models in the machine-to-machine context // Industrial Marketing Management. 2020. Vol. 84. P. 298-311. DOI: 10.1016/j.indmarman.2019.08.008.

60. Zhou K., Liu T., Zhou L. Industry 4.0: Towards future industrial opportunities and challenges // Proceedings of the 12th International Conference on Fuzzy Systems and Knowledge Discovery (FSKD 2015). Zhangjiajie, China, 15-17 August 2015. P. 2147-2152. DOI: $10.1109 /$ FSKD.2015.7382284.

61. Li L. Application of the internet of thing in green agricultural products supply chain management // Proceedings of the 2011 Fourth International Conference on Intelligent Computation Technology and Automation (ICICTA). Shenzhen, China, 28-29 March 2011. Vol. 1. P. 1022-1025. DOI: 10.1109/ICICTA.2011.256

62. Kopetz H. Real-time systems. Design principles for distributed embedded applications. Springer, 2011.

63. Xia F., Yang L., Wang L., Vinel A. Internet of things // International Journal of Communication Systems. 2012. Vol. 25. No 9. P. 1101-1102. DOI: $10.1002 /$ dac.2417.

64. Wortmann F. Flüchter K. Internet of things // Business \& Information Systems Engineering. 2015. Vol. 57. No 3. P. 221-224. DOI: $10.1007 / \mathrm{s} 12599-015-0383-3$.

65. IoT standards and protocols / Postcapes, 2017. [Электронный ресурc]: https://www.postscapes.com/internet-of-thingsprotocols/ (дата обрашения 15.09.2020).

66. Lee I., Lee K. The internet of things (IoT): Applications, investments, and challenges for enterprises // Business Horizons. 2015. Vol. 58. No 4. P. 431-440. DOI: 10.1016/j.bushor.2015.03.008

67. Zeinab K.A.M., Elmustafa S.A.A. Internet of things applications, challenges and related future technologies // World Scientific News. 2017. Vol. 67. No 2. P. 126-148.

68. Davies R. The internet of things opportunities and challenges / 2015. [Электронный pecypc]: https://epthinktank.eu/2015/05/21/ the-internet-of-things-opportunities-and-challenges/ (дата обращения 15.12.2020).

69. Porter M.E., Heppelmann J.E. How smart, connected products are transforming competition // Harvard Business Review. 2014. Vol. 92. P. 11-64.

70. Uckelmann D., Harrison M., Michahelles F. An architectural approach towards the future internet of things. Architecting the internet of things. Berlin, Heidelberg: Springer, 2011. DOI: 10.1007/978-3-642-19157-2 1.

71. Sun C. Application of RFID technology for logistics on internet of things // AASRI Procedia. 2012. Vol. 1. P. 106-111. DOI: 10.1016/j.aasri.2012.06.019.

72. Bandyopadhyay D., Sen J. Internet of things applications, challenges and related future technologies // Wireless Personal Communications. 2011. No 58. P. 49-69. DOI: $10.1007 / \mathrm{s} 11277-011-0288-5$.

73. The internet of everything: Smart things and their impact on business models / D.L. Langley [et al.] // Journal of Business Research. 2020. Vol. 122. P. 853-863. DOI: 10.1016/j.jbusres.2019.12.035

74. Yuvaraj S., Sangeetha M. Smart supply chain management using internet of things (IoT) and low power wireless communication systems // Proceedings of the IEEE 2016 International Conference on Wireless Communications, Signal Processing and Networking (WiSPNET). Chennai, India, 23-25 March 2016. P. 555-558. DOI: 10.1109/WiSPNET.2016.7566196.

75. Tao F., Ying Z., Xu L.D., Zhang L. IoT-based intelligent perception and access of manufacturing resource toward cloud manufacturing // IEEE Transactions on Industrial Informatics. 2014. Vol. 10. No 2. P. 1547-1557. DOI: 10.1109/TII.2014.2306397.

76. Gnimpieba Z.D.R., Nait-Sidi-Moh A., Durand D., Fortin J. Using internet of things technologies for a collaborative supply chain: Application to tracking of pallets and containers // Procedia Computer Science. 2015. Vol. 56. P. 550-557. DOI: 10.1016/j procs.2015.07.251.

77. A reference architecture for IoT-based logistic information systems in agri-food supply chains / C.N. Verdouw [et al.] // Enterprise Information Systems. 2018. Vol. 12. No 7. P. 755-779. DOI: 10.1080/17517575.2015.1072643.

78. Cost-benefit model for smart items in the supply chain / C. Decker [et al.] // The internet of things (C. Floerkemeier, M. Langheinrich, E. Fleisch, F. Mattern, S.E. Sarma, eds.). Lecture Notes in Computer Science. 2008. Vol. 4952. P. 155-172. DOI: 10.1007/978-3-540-78731-0_10.

79. Xu L.D. Information architecture for supply chain quality management // International Journal of Production Research. 2011. Vol. 49. No 1 . P. 183-198. DOI: $10.1080 / 00207543.2010 .508944$.

80. Chen R.-Y. Intelligent IoT-enabled system in green supply chain using integrated FCM method // International Journal of Business Analytics. 2015. Vol. 2. No 3. P. 47-66. DOI: 10.4018/IJBAN.2015070104.

81. Intelligent supply chain integration and management based on cloud of things / J. Yan [et al.] // International Journal of Distributed Sensor Networks. 2014. Vol. 10. No 3. Article No 624839. DOI: 10.1155/2014/624839.

82. Parry G.C., Brax S.A., Maull R.S., Ng I.C.L. Operationalising IoT for reverse supply: the development of use-visibility measures // Supply Chain Management. 2016. Vol. 21. No 2. P. 228-244. DOI: 10.1108/SCM-10-2015-0386.

83. Thoben K.D., Wiesner S., Wuest T. "Industrie 4.0" and smart manufacturing - A review of research issues and application examples // International Journal of Automation Technology. 2017. Vol. 11. No 1. P. 4-16.

84. Fleisch E. What is the internet of things? An economic perspective, business process and applications. White Paper WP-BIZAPP-053, 2010. [Электронный ресурc]: https://cocoa.ethz.ch/downloads/2014/06/none_AUTOIDLABS-WP-BIZAPP-53.pdf (дата обращения 15.12.2020)

85. Abdel-Basset M., Nabeeh N.A., El-Ghareeb H.A., Aboelfetouh A. Utilising neutrosophic theory to solve transition difficulties of IoT-based enterprises // Enterprise Information Systems. 2020. Vol. 14. No 9-10. P. 1304-1324. DOI: 10.1080/17517575.2019.1633690.

86. Gonzalez J. The impact of the internet of things on business and society. Foundation de la Innovation Bankinter, 2011. 
87. Poirier C.C., Bauer M.J. E-supply chain: Using the internet to revolutionize your business. San Francisco: Berrett-Koehler, 2000.

88. Vervest P., Preiss K., van Heck E., Pau L.-F. The emergence of smart business networks // Journal of Information Technology. 2004. Vol. 19. No 4. P. 228-233. DOI: 10.1057 /palgrave.jit.2000024.

89. Wirtz B.W., Weyerer J.C., Schichtel F.T. An integrative public IoT framework for smart government // Government Information Quarterly. 2019. Vol. 36. No 2. P. 333-345. DOI: 10.1016/j.giq.2018.07.001.

90. Challenges for adopting and implementing IoT in smart cities: An integrated MICMAC-ISM approach / M. Janssen [et al.] // Internet Research. 2019. Vol. 29. No 6. P. 1589-1616. DOI: 10.1108/INTR-06-2018-0252.

91. Abdel-Basset M., Manogaran G., Mohamed M. Internet of things (IoT) and its impact on supply chain: A framework for building smart, secure and efficient systems // Future Generation Computer Systems. 2018. Vol. 86. P. 614-628. DOI: 10.1016/j.future.2018.04.051.

92. Hu G., Lin Y., Shi Y., Guo L. Understanding business ecosystem using a 6C framework in Internet-of-Things-based sectors / K. Rong [et al.] // International Journal of Production Economics. 2015. Vol. 159. P. 41-55. DOI: 10.1016/j.ijpe.2014.09.003.

93. Cegielski C.G., Jones Farmer L.A., Wu Y., Hazen B.T. Adoption of cloud computing technologies in supply chains // International Journal of Logistics Management. 2012. Vol. 32. No 2. P. 184-211. DOI: 10.1108/09574091211265350.

94. Suguna S.K., Kumar S.N. Application of cloud computing and internet of things to improve supply chain processes // Edge computing: From hype to reality. Springer, 2019. P. 145-170.

95 Arlbjorn J.S., de Haas H.D., Munksgaard K.B. Exploring supply chain innovation // Logistics Research. 2011. Vol. 3. No 1. P. 3-18. DOI: $10.1007 / \mathrm{s} 12159-010-0044-3$.

96. Lee I. The Internet of Things (IoT) for supply chain innovation: a conceptual framework and analysis of Fortune 200 companies // Asia Pacific Journal of Innovation and Entrepreneurship. 2015. Vol. 9. No 1. P. 81-103.

97. Nozari H., Najafi E., Fallah M., Lotfi F.H. Quantitative analysis of key performance indicators of green supply chain in FMCG industries using non-linear fuzzy method // Mathematics. 2019. Vol. 7. No 11. Article No 1020. DOI: 10.3390/math7111020.

98. Kaur J., Sidhu R., Awasthi A., Srivastava S.K. A Pareto investigation on critical barriers in green supply chain management // International Journal of Management Science and Engineering Management. 2019. Vol. 14. No 2. P. 113-123. DOI: $10.1080 / 17509653.2018 .1504237$.

99. The role of big data analytics in industrial Internet of Things / M.H. Rehman [et al.] // Future Generation Computer Systems. 2019. No 99. P. 247-259. DOI: 10.1016/j.future.2019.04.020.

100. Yu M., Nagurney A. Competitive food supply chain networks with application to fresh produce // European Journal of Operational Research 2013. Vol. 224. No 2. P. 273-282. DOI: 10.1016/j.ejor.2012.07.033.

101. Ji G., Hu L., Tan K.H. A study on decision-making of food supply chain based on big data // Journal of Systems Science and Systems Engineering. 2017. No 26. P. 183-198. DOI: 10.1007/s11518-016-5320-6.

102. Osman A.M.S. A novel big data analytics framework for smart cities // Future Generation Computer Systems. 2019. No 91. P. 620-633.

\section{Об авторах}

\section{Хамед Нозари}

Ph.D.;

Lecturer, Department of Industrial Engineering, Islamic Azad University, Central Tehran Branch, Hamila Blvd., Poonak Sqr., Tehran 1469669191, Iran;

E-mail: Ham.nozari.eng@iauctb.ac.ir

ORCID: 0000-0002-6500-6708

\section{Мохаммад Фаллах}

Ph.D.;

Associated Professor, Department of Industrial Engineering, Islamic Azad University, Central Tehran Branch, Hamila Blvd., Poonak Sqr., Tehran 1469669191, Iran;

E-mail: Mohammad.fallah43@yahoo.com

ORCID: 0000-0001-5541-4284

\section{Хамед Каземипур}

Ph.D.;

Assistant Professor, Department of Industrial Engineering, Islamic Azad University, Central Tehran Branch, Hamila Blvd., Poonak Sqr., Tehran, 1469669191 Iran;

E-mail: Hkazemipoor@yahoo.com

ORCID: 0000-0002-1848-8927

\section{Сейед Эсмаил Найяфи}

Ph.D.;

Assistant Professor, Department of Industrial Engineering, Islamic Azad University, Science and Research Branch, Daneshgah Blvd., Simon Bulivar Blvd., Tehran 1477893855, Iran;

E-mail: E.najafi@srbiau.ac.ir

ORCID: 0000-0002-3125-4439 